\title{
The Nigerian Integrated Early Childhood Development Policy: Perspectives on literacy learning
}

Linda Newman, The University of Newcastle.*

Loveth Obed, The University of Newcastle.

\begin{abstract}
Many scholars and researchers now have a broadened vision of literacy that encompasses the social practices that surround literacy learning. What accompanies this vision is a shift towards thinking that children, and their families, can contribute actively to literacy learning by drawing on their strengths and life experiences to create and draw meaning from a broad range of everyday sources. For many, reading and writing from print-based texts is no longer considered the only, or most desirable, avenue to literacy learning. It is now recognised that children's social and cultural lives should be used as a resource for literacy learning. Using four literacy learning lenses, we examine the Nigerian National Policy for Integrated Early Childhood Development. These lenses are: collaboration with families, the role of educators, literacy-rich environments, and diversity and multimodality. Recent research around early literacy learning underpins our analysis to identify where the policy could more strongly refer to the role of families and educators and to argue that there is scope for greater attention to early literacy learning in the policy.
\end{abstract}

Keywords: early childhood education, literacy, sociocultural, Nigerian education, social practices, early literacy

*Email address: linda.newman@newcastle.edu.au.

South African Journal of Childhood Education | 2015 5(1): 125-141 | ISSN: 2223-7674 |๔ UJ

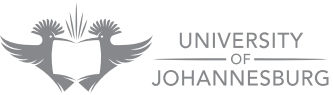




\section{Introduction}

Contemporary views of literacy have broadened over the last twenty years from a view of literacy as print-based reading and writing, drawing on a set of individual skills, to one that includes social practices which nurture reading and writing. More recent conceptualisations include multimodal literacies delivered through various means; for example, audio and visual materials that recognise and draw on different social and cultural contexts (Arthur, Woodrow, Newman \& Staples 2011; Perez 2004; Street 2003; Street n.d.). With this shift comes the idea that children are competent people and citizens in their own right (Woodhead 2008), and that being 'literate' is much broader in scope, implying that people who were once considered in deficit terms due to a lack of reading and writing skills may now be considered as literate, albeit not alphabetically or 'print' literate. Literacy, once considered to be only for the powerful and privileged, is now seen by many to exist in many more places than only within book-based texts (McLachlan, Nicholson, Fielding-Barnsley et al 2013). In effect, this means that the cultural practices that reflect a 'decoding' of the world reach beyond the printed word. However, at the same time, we would argue that a person who is able to read and write has greater opportunity for personal empowerment in the $21^{\text {st }}$ century.

Also inherent in this shift in view is a greater realisation that alphabetical (and logographic, in the case of non-alphabetical languages) literacy learning in the early years is an emergent process, with many underpinning processes preceding the learning of letters and their correspondence with sounds. Vocabulary development and an understanding of word and sentence structure, punctuation and print concepts and book-handling skills, together with phonemic awareness (rhyme and sound) are all components of early literacy (Arthur et al 2011). In the course of their interaction with family members and the community, children participate in different forms of literacy related to their daily social and cultural activities that enrich and draw on their funds of knowledge (Arthur et al 2011; Gonzalez, Moll \& Amanti 2005). Gonzalez et al (ibid) conceptualise funds of knowledge as historically accumulated cultural resources (knowledge and skills) which children bring from their families to the school or early childhood development (ECD) setting. Thus, when educators understand the key role of families and communities in children's learning, and recognise it by integrating and infusing the funds of knowledge that children bring from their homes into an integrated curriculum, learning becomes relevant to the needs and interests of children. Early literacy learning through play-based activities that recognise diversity and difference with regard to their family background also provides children the opportunity to develop their individual attitudes and learning dispositions, which enhances their transition from home to school (Arthur et al 2011).

Some contemporary themes in early literacy learning are discussed in this paper for the purpose of reviewing the National Policy for Integrated Early Childhood Development (IECD) in Nigeria with regard to these themes. Recent research and scholarship are used to analyse the policy in terms of its focus on the contemporary scholarship of literacy learning in very young children, and to examine whether the policy sufficiently guides the development of literacy learning for children, families and 
educators in Nigeria. The key early literacy themes used for this analysis are drawn from the literature, namely collaboration with families and the role of educators, literacy-rich environments, diversity of learner population and multimodality of instruction.

Our examination of the policy has found that it adopts a multisectorial approach to early childhood education, with the aim of expanding, universalising and integrating the efforts of various sectors for effective intervention and coordination of programmes and the optimal development of children from birth to five years of age (FRN 2007). Although the policy emphasises collaboration and effective participation by all stakeholders, its main thrust is the general well-being and development of children, which includes educational provisions. While an educational intent can be inferred in, for example, Objective 5 ('Spirit of enquiry') and Objective 9 ('Achieve full potential'), there is little of an explicit nature to guide educators, such as what the tools of learning to read imply at the level of the individual child, including what pedagogy will be followed. We argue that the policy provides a necessary but insufficient start to the integration of early childhood development in Nigeria and is almost silent on the issue of early childhood literacy.

\section{Developing early literacy from social and psychological sources}

Based on work with families in impoverished regions in northern Chile, Woodrow, Newman, Arthur \& Staples (2011) show that strategies developed by educators in early childhood centres to find out about and connect to family funds of knowledge (Hedges, Cullen \& Jordan 2011; Moll, Amanti, Neff \& Gonzalez 1992) have proven very powerful in connecting educators and families. Families have seen that their knowledge and experiences are valued by educators and have become more likely to engage in educational activities. Moreover, children are more motivated to learn when learning is related to what they already know. Woodrow et al (2011) also demonstrate that parents are often willing to share their views, knowledge and experiences with educators in a relaxed and friendly atmosphere. Evidence by McLachlan (2007) also revealed that children's participation in literacy-related activities outside the school environment provides them with the cultural, cognitive and linguistic competence and flexibility they need in order to survive in the broader society.

Although there are divergent views as to what constitutes emergent literacy, Whitehurst and Lonigan (1998, in McLachlan 2007) describe emergent literacy and literacy acquisition as a continuous developmental process starting early in life, rather than an activity that begins with the onset of formal preschool or school education, and that it continues well into primary school, based on the first sound and word correlations learned at the outset (Yoncheva, Wise \& McCandliss 2015). This perspective provides a more encompassing and broad definition of literacy and its early beginnings as occurring well before the acquisition of conventional forms of reading and writing. As Whitehurst and Lonigan suggested, "there is no clear demarcation between reading and pre-reading" (1998, in McLachlan 2007:1), as was 
once thought. Children take their first steps into the world of reading by learning the distinct sounds of the language in which they will be reading.

Teale \& Sulzby (1986, cited in McLachlan 2007) also noted that studies in emergent literacy in the 1970 s and 1980 s had shown that reading and writing skills will develop, provided that the process is supported by participation in literacy activities in the home environment, the community and the school setting. Similarly, Woodrow, Arthur and Newman (2014), in their ' 5 Literacy Keys', include play with literacy materials and emphasize the role of families and educators as crucial to the development of early literacy. Many participants in the daily literacy learning environments where children engage in ongoing social practice, and get to know how a literate environment operates, may not fully realise the value of the contributions they make to the entire process. Barratt-Pugh (2000) noted that literacy learning patterns differ among children and among cultures, as does what actually constitutes literacy and how it should be acquired.

Studies have demonstrated that active engagement in social and cultural activities enhances children's learning and understanding of a range of literacy practices (MacNaughton 1995, cited in Barratt-Pugh 2000). Such an expanded view of literacy as co-constructed in interaction with other children and adults involves social, political and cultural activities, the ability to decode deeper meanings from both print and electronic texts, and learning the ability to decipher phonemes, graphemes and the signs that represent words, part of words, and sentences.

Jones Diaz (2007) observed, for example, that some children demonstrate more sophistication in their use of mobile technologies than their parents, knowing how to navigate devices, accessing music and videos, and so forth. Jones Diaz (ibid) also noted that classroom practices that fail to draw on the knowledge that children gain outside the school setting put them at a disadvantage. This type of generic pedagogical approach can be applied to all learning, whether in education centres or school. Expanding reading to a wider social life and bringing it into the classroom is an accepted pedagogical device, but requires educators to face the challenge of recognising the different faces of diversity that emerge from their particular sociocultural environments and the world of new technologies, as well as harnessing and integrating these into their pedagogical practices to the maximum benefit of children and families.

Studies by Moll et al (1992) show that teaching strategies that draw upon the practices and experiences of children's daily life - especially those regarded as 'poor' in terms of economic status and the experiences available to them - are very effective for literacy and other learning. 'Household' knowledge, which may include farming and animal management, stories about family origins, or skills and activities related to trading and other forms of business, is "historically accumulated and culturally developed bodies of knowledge and skills essential for individual functioning and well-being" (ibid:133). Children are seen as active participants in a wide range of activities, including, for example, contributing their share to the economic running of the household or using their knowledge of English to mediate between the family 
and the outside world. These household experiences and knowledge provide insight into the activities children engage in outside the school setting and can be profitably used as learning resources in classrooms. Children frequently observe and participate in diverse occupations involving mathematical procedures that are often based on intuition rather than academic knowledge, such as carpentry and dressmaking, and teaching and learning processes may capitalise on these experiences. As Hedges et al (2011) and Zipin, Sellar \& Hattam (2012) also argue, recognising such knowledge and using it as a foundation for developing appropriate curricula would change the negative perception of children from poor families and communities as being disadvantaged or 'at risk'.

However, knowledge of literacy research and concepts and a willingness to get to know families do not per se guarantee successful literacy learning. The role of the educator (family member and/or teacher) is crucial to literacy learning success (Woodrow et al 2014). Sustained shared thinking (SST), a concept that has emerged from studies in the United Kingdom (UK) (see, for example, Siraj-Blatchford, Sylva, Gilden \& Bell 2002), is a pedagogical strategy that involves problem solving by two or more individuals who each contributes their ideas to develop and extend learning. Studies from Blatchford et al's (ibid) Effective Provision of Preschool Education project (EPPE) show that SST contributes to early childhood centre quality and current and future learning success. If properly harnessed and integrated into the teaching and learning process, this strategy is potentially very useful for early literacy learning, as children benefit from reflective thinking and genuine involvement to create understanding with others. A knowledgeable and experienced educator scaffolds learning and strengthens children's self-confidence and independence by means of deep and authentic learning outcomes (Newman, Arthur, Staples \& Woodrow 2011). Home-based activities such as cooking, gardening or cleaning could also create opportunities for sustained shared thinking and creativity, with adults and children engaging in genuine curiosity-based conversations as they investigate, reflect on and question what is happening as they work together. By developing strong ties with families, educators enhance possibilities for the use of SST as a literacy learning strategy, both at home and in formal educational settings. Rather than yield to mandates that decontextualize learning by teaching according to a prescribed curriculum, educators should be able to interpret the curriculum and associated tasks in such a way that the classroom becomes a creative space (Comber 2011). Educators who understand the power and potential of creating contextualised and authentic curricula can strive to give meaning and significance to their tasks and activities, so that literacy learning becomes an engaging and meaningful activity.

Family members are of course the first and extremely important educators, though the influence of the home environment is a complex area of study, as there are many variables. Attention has been paid to the influence of maternal educational levels, due to the relationships between socio-economic status and literacy skills. It may be however that low educational levels can be mediated by positive reading beliefs (Cottone 2012). Evidence now shows the shortcomings in assuming that 
parents from poor homes or with lower levels of education do not, or cannot, support their children's education. Studies by Gonzalez et al (2005) and McLachlan et al (2013) show that mothers' educational level or economic situation does not necessarily matter as much as a literacy-rich home environment, which can be provided by parents who are not educated themselves. It bears consideration that the problem may be associated with a disconnection between the home and school environments, rather than the quality of the home literacy environment. This argument is borne out by Newman, Arthur, Staples \& Woodrow 2006 (in press), who showed that poor families in northern Chile do have high aspirations for their children's learning and do engage in literacy-based activities at home.

A literacy-rich environment, whether at home or in the ECD or school setting, has been shown to enhance literacy development in the early years (McLachlan et al 2013). A literacy-rich environment is one that is well resourced with literacy materials and where children experience effective teaching and learning activities that make a difference to their literacy learning outcomes (ibid). A richly stocked play area - which may include newspapers and magazines and a range of literacy resources and diverse print materials, such as posters, food packaging, recipe books, collage materials, and signs and labels - and interactive reading or story-telling sessions may facilitate the acquisition of literacy knowledge and skills through socio-dramatic play, as wellplanned physical spaces spark children's interest (Morrow \& Schickendanz 2006, cited in McLachlan et al 2013). Resources could include e-games and e-books, picture books, picture storybooks and easy-to-read books, traditional literature, poetry, informational books, biographies, novels, riddles and joke books, brochures, packages and everyday materials containing print, such as magazines, newspapers. Literacy materials such as pencils and notepads in play areas, provide for activities according to children's individual interests (McLachlan et al 2013). Materials do not necessarily need to cost a lot of money.

However, as Justice and Pullen (2003) point out, although environments enriched with literacy learning materials promote learning, further gains in literacy understanding are realized if adult mediation is part of the process. Mediation at home may take the form of reading and telling stories or talking and discussion, which make the sounds of the language clear. Systematic instruction, as it happens in schools, teaches the deciphering and decoding of small grain units of written language and partners them with sounds that the child knows (Yoncheva et al 2015). It is only after this instruction and practice, and with the help of the vocabulary knowledge that they have built up socially, especially before they learned to read, that children learn to read and later to understand what they have read.

Based on a review of three major areas associated with emergent literacy, namely phonological awareness, print awareness and oral language development, Justice and Pullen (2003:110) demonstrate that children who are provided with "literacy-rich environments and adult mediation display greater gains in print awareness, particularly alphabet knowledge and print recognition". Print awareness in itself is not yet reading. Thus, educators need knowledge of reading pedagogy and expertise in how to 
sequence the teaching of reading in order to design a literacy-rich and pedagogically rich environment for greater learning outcomes. Furthermore, educators can help family members to recognise opportunities for scaffolding literacy opportunities in everyday home situations, such as cooking or shopping (Newman et al 2016 in press).

\section{The role of new technologies in fostering literacy awareness}

An awareness of multiple texts, combined with an appreciation of the value of multiple levels of literacy, challenges educators to broaden their understanding of what 'counts' as literacy, and to engage their students in a wide range of new text forms (McLachlan et al 2013). Contemporary educators are now called upon to engage with rapidly changing modes of communication, increased cultural diversity and globalisation as issues affecting the whole learning process. As demonstrated by Hill (2010) in a teacher-researcher project in South Australia, contrary to the expectations of the teachers, four- to eight-year-old children demonstrated considerable knowledge of the use of different information and communication technologies than those that the schools had to offer. Four-year-olds were observed to be able to use search engines to access various websites and play interactive online games. Similar experiences were reported by families from the poorest communities in northern Chile (Newman et al 2016 in press). The teacher-researchers in Hill's study "viewed literacy as not print alone, nor language, but the ways meaning is represented in signs, logos, music, animation and forms of multimedia" (Hill 2010:326). The abundance of new technologies enables educators to develop literacy learning in children using a range of multimodal forms, such as colour and visual design, animation, music, dance, video, interactive chat rooms, webcams and written text, or a combination of these (Ljungdahl 2010). However, it is important to note that despite the high level of engagement with digital technologies, traditional print-based text was still found to be very useful in many digital contexts. Interaction and mediation by educators also remains important, as various software packages, strategies and techniques are required to scaffold reading and writing instruction and facilitate the learning process.

The reading of storybooks in the early years is a form of literacy practice that provides opportunities for children to develop awareness of the knowledge and skills involved in reading, acquire new vocabulary, understand stories and narratives (and other child genres), and decontextualize language (McLachlan 2007). According to Stanovich (1986, cited in McLachlan 2007), there is strong evidence of a relationship between vocabulary knowledge and the amount of reading experience when the child is still a listener, with another person demonstrating the art and skill of reading. Stanovich (ibid) demonstrated that children with large vocabularies and an awareness of reading skills learn more words and read better when they begin to read than their peers who have smaller vocabularies. The latter children also read slowly, often exhibiting little enjoyment in the activity, and their vocabulary development was usually slower, thus inhibiting their reading ability. There is strong evidence that reading storybooks (and other child genre books) equips children with the knowledge and skills required for literacy learning and also predicts reading achievement in later life (Saracho \& Spodek 2010, cited in McLachlan et al 2013). 


\section{Preparing new readers from diverse backgrounds in multilingual classrooms: the Australian Aboriginal experience}

Diversity and difference in classroom populations are critical issues in early childhood discourse (Rhedding-Jones 2005), especially in literacy learning. It benefits educators and children alike when educators view diversity in a bilingual or multilingual classroom as an advantage and take up the challenge of making optimal use of this diversity by creating literacy activities around it. Curricula should be linguistically and culturally relevant, with no language or group accorded more value or recognition than others (ibid). Children should be encouraged to explore languages other than their own, and the classroom environment should, ideally, showcase linguistic materials and practices from diverse backgrounds to show that everyone is recognised and appreciated. Healy (2008) demonstrates a 'Learning by Design' model that seeks to address the issue of children having difficulty connecting to classroom practices that they find strange, possibly because their knowledge has often been ignored by conventional teaching practices. As Healy observes, deeper learning is achieved when individual differences are recognised and respected as a basis on which new knowledge can be developed.

Australian Aboriginal literacies provide an interesting example of how cultural heritage may be used as a valuable resource for literacy learning (Martin 2008, cited in Healy 2008). Aboriginal knowledge emanates from 'relatedness', which is expressed through oral stories that often express deeper knowledge and not mere representations of information. Thus, stories occupy a central position in Aboriginal literacies and are consequently embedded in the literacies developed by Australian Aboriginal children. A multiliteracies approach accommodates all learners, irrespective of their backgrounds, providing them with the opportunity to express their knowledge and themselves and to not be excluded or silenced by the curriculum. Classroom activities in classes that include Aboriginal children could therefore connect to the funds of knowledge manifested in Aboriginal oral story traditions and utilize them as an authentic literacy curriculum resource to increase vocabulary development and engage these children in sustained shared thinking. It is the duty of the educator to interpret the curriculum in such a way that children are not excluded from learning opportunities because of their historical, social, linguistic or cultural background. Diversity and difference can be harnessed to produce a culturally and linguistically rich pedagogical practice from the earliest years.

\section{The Nigerian IECD policy}

The next section of this paper provides an analysis of the National Policy for Integrated Early Childhood Development in Nigeria (IECD) from the perspective of contemporary early literacy learning theory, with particular attention to the themes reviewed above, namely collaboration with families, the role of educators, literacy-rich environments, and diversity and multimodality.

The Nigerian National Policy on Education, which informs the IECD, describes early childhood education as the education provided to children in a pre-primary educational 
institution, including crèches, nursery schools and kindergarten (FRN 2013). Despite government policies and interventions, the early childhood education sector in Nigeria is dominated by private practitioners and hence characterised by challenges ranging from inappropriate curricula and teacher training and recruitment to the provision of child-friendly facilities and environments (Onu, Obiozor, Agbo \& Ezeanwu 2010). Early childhood centres usually operate from private homes, government-owned primary schools, industrial and business premises, churches and mosques (Ibiam \& Ugwu 2009). Qualification requirements are minimal and mostly non-mandatory: teachers of three to five-year-olds should "[p]referably [be] NCE [Nigerian Certificate in Education] holders, [... ] with at least a senior secondary school certificate, proficiency certificate"; caregivers may be "[a]nyone with basic literacy and aged not less than 21 years"; and 'helpers' should be aged "[n]ot less than 21 years, preferably having primary six or basic literacy certificate" (NERDC n.d.). In a survey by Ezirim (2004) of nursery school caregivers in south-eastern Nigeria, less than $20 \%$ of teachers and caregivers had obtained the NCE (the three-year, minimum professional qualification for teachers in the Nigerian education system; this basic training is recommended only for the early years in the minimum standards (NERDC n.d.). According to Ezirim (ibid), many of the teachers in the study were secondary school leavers awaiting admission to tertiary institutions. Consequently, they were usually poorly remunerated and illmotivated, resulting in a high turnover of teachers and caregivers. The implications for children were inadequate care and education, which were likely to limit their potential for development and literacy acquisition in the critical early years.

Given its multisectorial approach, the IECD policy is the first of its kind in the history of education in Nigeria (Agusiobo 2007). The overarching goal of the IECD is to

[...] expand, universalise and integrate interventions from various sectors in early childhood development for effective implementation and coordination of programmes that will optimise development for children age 0-5 years in Nigeria.

(FRN 2007:4)

The policy aims to integrate interventions by various sectors that have been working in different ways and at various levels to achieve a better life for Nigerian children. The policy foregrounds a scientific (developmental) approach to children's development, with the foreword explicitly stating the intention to "provide interventions for cognitive, physical, social, moral and emotional development of the child" (FRN 2007:i). Developmental approaches have however been criticised in the last two decades for shortcomings that essentialize a 'universal child' based on middle-class Western norms of development (Dahlberg, Moss \& Pence 1999). In her discussion of early childhood education in the formerly colonised country of Chile, Galdames (2011) argues that globalised (developmental) discourses about children are overly influenced by colonial traditions that ignore the sociocultural realities of children's lives and risk creating social injustices. 
The IECD objectives include:

- $\quad$ the provision of care and support that will uphold the rights of children to good nutrition and health, a healthy and safe environment, psycho-social stimulation, and protection and participation;

- inculcating a spirit of enquiry and creativity in children through the exploration of nature, the environment, art and music, playing with toys, etcetera;

- the provision of adequate care and supervision for children while their parents/ guardians are at work;

- $\quad$ inculcating acceptable social and culturally appropriate norms, values and beliefs;

- $\quad$ preparing children to adapt successfully when their current context changes; and

- developing healthy, well-nourished and adequately stimulated children who are able to achieve their full potential.

(FRN 2007:19-20)

We consider these objectives as laudable and necessary, but also as broad and insufficient in terms of recognition of child and family realities. With the exception of Section 9.2 (FRN 2007:16-17), which addresses 'cultural appropriateness' for families, and the fourth bullet point above ('inculcating acceptable social and culturally appropriate norms, values and beliefs'), the policy is almost silent with regard to the social, cultural and historical lives of children and families and fails to recognise diversity in its reference to 'acceptable' and 'appropriate' norms, values and beliefs. What is regarded as 'acceptable' and 'appropriate' is open to wide interpretation, but is likely to perpetuate mainstream views and ignore or suppress diversity. As our primary interest in reviewing the policy here is to gauge its value for literacy education, we note that, apart from the learning potential implied in 'psycho-social stimulation', 'spirit of enquiry', and 'preparing children to adapt successfully', there is no explicit reference to education, curriculum or pedagogy. Despite the fact that the National Policy on Education (NPE) is premised on the general well-being and development of children, which includes sound educational provision in the early years, the IECD provides little detail regarding the provision of "quality education" (FRN 2013:5).

According to the NPE, the "purpose of Early Child Care, Development and Education shall be to:

- $\quad$ effect a smooth transition from the home to the school;

- $\quad$ prepare the child for the primary level of education;

- $\quad$ provide adequate care, supervision and security for the children while their parents are at work;

- $\quad$ inculcate social, moral norms and values; 
- inculcate in the child the spirit of enquiry and creativity through the exploration of nature, the environment, art, music and the use of toys, etc.;

- develop a sense of co-operation and team-spirit;

- $\quad$ stimulate in the child good habits, including good health habits; and

- teach the rudiments of numbers, letters, colours, shapes, forms, etc., through play"

(FRN 2013:5)

Implicit in both the NPE and IECD is the expectation that all stakeholders will collaborate and synergise to ensure optimal efficacy of their various efforts towards achieving the goals enshrined in these policies. The aims of the IECD include the provision of adequate care and supervision for children while their parents/guardians are at work, thus positioning children as 'economic factors' in the development of the country (Galdames 2011) who can either help or hinder economic development. There is little recognition of children as citizens and learners in their own right. Moreover, this objective fails to fully recognize the role of families, other than as economic producers. While the IECD acknowledges the need for collaborative efforts in order to achieve holistic development of children and encourages effective participation by all stakeholders, the family is not recognized as a key stakeholder in children's learning. From a sociocultural perspective on learning and development, this is a significant shortcoming of the IECD.

With regard to the contemporary themes in early literacy outlined in the first part of this paper, the IECD neither defines specific roles for the educator in the early learning process nor addresses literacy development in any specific way. Although the country is a signatory of various international agreements, such as Education For All (EFA) (UNESCO 1990) and the Millennium Development Goals (MDGs) (UN 2012), Nigeria's IECD policy does not effectively detail the implications of the well-researched potential of early literacy learning (FRN 2007) and contemporary themes in early literacy.

The specific role assigned to the Federal Ministry of Education in Section 8.5 of the IECD is to:

- regulate the establishment and registration of pre-school facilities (for children four- to five-years of age);

- ensure the implementation of the provisions of the Universal Basic Education (UBE) Act for the establishment of IECD centres in public primary and junior secondary schools;

- ensure compliance with and innovations to minimum standard prescriptions, especially as they relate to IECD curriculum development programmes and activities;

- develop and implement IECD capacity-building programmes for parents, caregivers and teachers; and 
- develop and implement educational support services to Orphans and Vulnerable Children (OVC).

(FRN 2007:13)

While the IECD recognises and encourages participation by parents, caregivers, communities, religious groups, civil society, the media, the private sector and relevant tertiary institutions as partners in the process, and acknowledges the need for capacity building, this is not reflected in the previously quoted purposes of the policy (NFR 2007). In addition, the policy recognises the need for a play-based environment and provides for a partnership with families, communities and other stakeholders, including government ministries and agencies, in Section 10 (ibid:19); however, it does not provide a clearly defined role for the educator, and as such does not give due recognition to the key position occupied by educators in literacy learning and the childhood development process or provide guidance for the relationship between educators and families. It stipulates a five-year period after which observable improvements would be expected in the areas of health, education and sanitation, and provides for diverse plans and interventions by various stakeholders through coordinating committees with specific roles and responsibilities at the national, state, local government and community level.

To ensure maximum impact, relevant government ministries and agencies are also charged with

- $\quad$ ensuring policy sensitization and advocacy for IECD involvement;

- $\quad$ making special provisions for IECD activities and programmes in their line budgets;

- actively participating in the National or State IECD Coordinating Committee;

- monitoring and evaluating involvement in IECD implementation for effective baseline data inputs and feedback for the National Coordinating Committee; and

- facilitating IECD-related research.

(FRN 2007:12).

The IECD emphasises the need for a play-based environment with a focus on child stimulation through relevant educational materials and toys, to be provided at the home and community levels. It also encourages culturally desirable and appropriate practices and emphasizes the key roles of family and community for different age groups (birth to twelve months; one to three years of age; three to five years of age); however, there is no elaboration of what these roles are. Nor does it expand on the need for support for emergent literacy and literacy acquisition practices, which have been shown in part one of this paper to be important long before the commencement of conventional school education. The policy encourages the media to print or broadcast culturally appropriate material to promote the indigenous knowledge that children bring to the ECD centre from their homes and communities, 
but is not explicit about inclusivity with regard to cultural and linguistic diversity. This shortcoming provides an exciting avenue for further efforts to tap into family funds of knowledge as a resource, a practice that is not yet in evidence in classrooms. Educators should also be provided with information about the development of literacy-rich environments in order to support and enhance their attempts to scaffold literacy learning in young children. Furthermore, drawing on family strengths and diversities in this way carries the potential to change the way educators view families: from a perception of deficiency and children being at risk, to one that focuses on partnership and collaboration.

There is also a provision in the IECD for local governments to establish model early childhood centres with 'best practice', which are to be replicated at various community levels; however, there is little detail about what is considered as 'best practice'. These centres are also intended to empower parents and other family members with the necessary knowledge to enable them to play their vital role in the development process, thereby improving service delivery at this level. In order to further address the challenges in the sector, the policy also mandates national and state governments to create an enabling environment for research and to ensure that research findings are properly disseminated. Monitoring and evaluation mechanisms are to be put in place for the smooth running and sustainability of IECD programmes.

\section{Conclusion: Towards collaboration in a multisectorial approach}

In summary, in order to provide an enabling environment to facilitate a smooth transition for children from home to a primary school setting, early childhood education in Nigeria has progressed from a single-sector effort to a multisectorial approach. In this regard, the National Policy for Integrated Early Childhood Development (IECD) in Nigeria is a bold step towards providing a solid foundation for lifelong learning and development for every Nigerian child. The policy emphasises commitment by all levels of government and various other stakeholders, including the community and family members.

However, it is our view that the policy would be further enhanced, and optimal benefits derived from it, if the limiting developmental discourse (Galdames 2011) that informs it were broadened and deepened through recognition of the social, cultural and historical realities of children's lives. This would help to attenuate the risk of social injustice towards poor and diverse families. Furthermore, learning outcomes may improve if the curriculum and, of specific interest to us, literacy aspects were accorded greater emphasis, with special consideration of contemporary themes in early literacy and learning-based play, particularly as these play out as social practices in children's daily lives. A repositioning of the theoretical approach of the policy from a developmental focus towards a greater emphasis on the sociocultural relationships between children, families, educators and communities could expand possibilities for meaningful learning. This would allow the rhetoric of the IECD regarding the empowerment of families (FRN 2007:16) to be translated into practical action in ECD centres, with educators embedding families into children's learning activities. There 
is further potential here for drawing on family diversities and funds of knowledge (Hedges et al 2011) to enrich children's learning and make it relevant to their social realities (Moll et al 1992). In order to achieve this, the notion of 'best practice' - which is often based on middle-class, essentialized, Western norms (Galdames 2011) - could be broadened to include local social and cultural realities. Moreover, if the crucial role of educators (McLachlan et al 2013) with professional training and expertise were clearly elaborated, it would give more credence to the policy and enhance its potential for long-term effectiveness, as demonstrated in the EPPE study (Siraj-Blatchford et al 2002), where the presence of highly qualified teachers translated directly into higher quality education. We note that, although the issues of 'best practice' and playbased learning are raised, there is no mention of 'literacy-rich' play, which is strongly advocated in the literature (for example, McLachlan et al 2013); in addition, the IECD missed the opportunity to advocate the use of effective teaching strategies such as sustained shared thinking (SST) (Siraj-Blatchford et al 2002), which have been shown to be very effective in other contexts. A broadened scope in the policy would reflect global trends and practices, with strategies for effective implementation, in order to achieve desirable learning outcomes and facilitate the total development of Nigerian children. The policy could go another step further by including clear objectives in terms of curriculum principles and pedagogical practices that explicitly integrate the efforts of all stakeholders, including families and early educators.

\section{References}

Agusiobo, B.C. 2007. National Policy for Integrated Early Childhood Development in Nigeria. UNESCO-IICBA Bi-annual Newsletter, 9(2):8-10.

Arthur, L., Woodrow, C., Newman, L. \& Staples, K. 2011. Literacy. Connecting Research and Practice Series, 2. Sydney: University of Western Sydney, Futuro Infantil Hoy research team.

Australian Government Department of Education, Employment and Workplace Relations. 2009. Belonging, being and becoming. The early years learning framework for Australia. Australia: Council of Australian Governments (COAG).

Barratt-Pugh, C. 2000. The socio-cultural context of literacy learning. In: C. Barratt-Pugh \& M. Rohi (Eds). Literacy learning in the early years. Crows Nest, NSW: Allen \& Unwin. 1-26.

Comber, B. 2011. Making space for place-making pedagogies, stretching the normative mandated literacy curriculum. Contemporary Issues in Early Childhood, 12(4):343-348.

Cottone, E. 2012. Preschoolers' emergent literacy skills: The mediating role of maternal reading beliefs. Early Education and Development, 23:351-372.

Dahlberg, G., Moss, P. \& Pence, A. 1999. Beyond quality in early childhood education. London: Falmer.

Dickenson, D.K. \& Neuman, S.B. (Eds). 2006. Handbook of Early Literacy Research, Vol 2. New York: Guilford. 
Ezirim, M. 2004. A survey of nursery school caregivers in the South Eastern States of Nigeria. UNICEF Zone A Office Report.

FRN (Federal Republic of Nigeria). 2007. National Policy for Integrated Early Childhood Development in Nigeria. Lagos: NERDC Press.

FRN (Federal Republic of Nigeria). 2013. National Policy on Education. Lagos: NERDC Press.

Galdames. P. 2011. Chilean early childhood education as a promoter of social justice: Challenging neo-colonial trajectories of knowledge. International Studies in Education, 12:106-124.

Gonzalez, N., Moll, L. \& Amanti, C. 2005. Introduction: Theorizing practices. In: N. Gonzalez, L. Moll \& C. Amanti (Eds). Funds of knowledge: Theorizing practices in households, communities, and classrooms. Mahwah, NJ: Lawrence Erlbaum Associates. 1-24.

Healy, A. 2008. Expanding student capacities: Learning by Design Pedagogy. In: A. Healy (Ed). Multiliteracies and diversity in education - New pedagogies for expanding landscapes. Sydney: Oxford University Press. 2-29.

Hedges, H., Cullen, J. \& Jordan, B. 2011. Early years curriculum. Funds of knowledge as a conceptual framework for children's interests. Journal of Curriculum Studies, $43(2) 185-205$

Hill, S. 2010. The millennium generation - Teacher-researchers exploring new forms of literacy. Journal of Early Childhood Literacy, 10(3):314-340.

Ibiam, J. \& Ugwu, G.C. 2009. Government quality control measures in pre-primary education, Problems of implementation and the way forward. Review of Education, Institute of Education Journal, University of Nigeria, Nsukka, 20(1).

Jones Diaz, C. 2007. Literacy as social practice. In: L. Makin, C. Jones Diaz \& C. McLachlan (Eds). Literacies in Childhood: changing views, challenging practice. Sydney: Maclennan \& Petty. 31-42.

Justice, L.M. \& Pullen, P.C. 2003. Promising interventions for promoting emergent literacy skills - three evidence-based approaches. Topics in Early Childhood Education, 23(3):99-113.

Ljungdahl, L. 2010. Multiliteracies and Technology. In: G. Winch (Ed). Literacy, reading, writing and children's literature. $4^{\text {th }}$ Edition. 399-422.

MacNaughton, G., Hughes, P. \& Smith, K. 2008. (Eds). Young children as active citizens Principles, policies and pedagogies. Newcastle: Cambridge Scholars.

Martin, K. 2008. The intersection of Aboriginal knowledges, Aboriginal literacies and new learning pedagogy for Aboriginal students. In: A. Healy (Ed). Multiliteracies and diversity in education - New pedagogies for expanding landscapes. Sydney: Oxford University Press. 58-81.

McLachlan, C. 2007. Emergent literacy. In: L. Makin, C.J. Diaz \& C. McLachlan (Eds). Literacies in childhood - Changing views, challenging practice. Sydney: Elsevier Australia. 15-30. 
McLachlan, C., Nicholson, T., Fielding-Barnsley, R., Mercer, L. \& Ohi, S. 2013. Literacy in early childhood and primary education: Issues, challenges and solutions. Melbourne: Cambridge University Press.

Moll, L.C., Amanti, C., Neff, D. \& Gonzalez, N. 1992. Funds of knowledge for teaching - Using a qualitative approach to connect homes and classrooms. Theory into Practice, 31(2):132-141.

Morrow, L.M. \& Schickendanz, J.A. 2006. The relationship between sociodramatic play and literacy development. In: D.K. Dickenson \& S.B. Neuman (Eds). Handbook of Early Literacy Research. Vol 2. New York: Guilford. 269-280.

NERDC (Nigerian Education and Research Development Council). n.d. National minimum standard for early childhood centres in Nigeria. Lagos: Nigerian Education and Research Development Council.

Newman, L., Arthur, L., Staples, K. \& Woodrow, C. 2011. Sustained shared thinking in early childhood pedagogical practice. Connecting Research and Practice Series. Theme 5. Sydney: University of Western Sydney.

Newman, L., Arthur, L., Staples, K. \& Woodrow, C. 2016 (in press). Accessing Family Knowledge: Conceptualising opportunities for recognition of family engagement in young children's literacy learning. Australian Journal of Early Childhood.

Onu, V.C., Obiozor, W.E., Agbo, O.E. \& Ezeanwu, C. 2010. Integration and innovation in early childhood education in Nigeria: Implications for quality teacher production. African Journal of Teacher Education, 1(1):209-221.

Pennington, J.L., Brock, C.H., Palmer, T. \& Wolters, L. 2013. Opportunities to teach: confronting the deskilling of teachers through the development of teacher knowledge of multiple literacies. Teachers and teaching: Theory and practice, 19(1):63-77.

Perez, B. (Ed). 2004. Sociocultural Contexts of Language and Literacy. Mahwah, NJ: Lawrence Erlbaum \& Associates.

Rhedding-Jones, J. 2005. Questioning Diversity. In: N. Yelland (Ed). Critical issues in early childhood education. Maidenhead: Open University Press. 131-145.

Robinson, K.H. \& Jones Diaz, C. 2006. "It's more than black dolls and brown paint" - Critical multiculturalism, whiteness and early childhood education. In: Diversity and difference in early childhood education: Issues for theory and practice. Berkshire: Open University Press. 64-81.

Saracho, O.N. \& Spodek, B. 2010. Parents and children engaging in storybook reading. Early Child Development and Care, 180(10):1379-1389.

Siraj-Blatchford, I., Sylva, K., Gilden, R. \& Bell, D. 2002. Researching effective pedagogy in the early years. London: Department for Education and Skills.

Stanovich, K. 1986. Mathew effects in reading: Some consequences of individual differences in the acquisition of literacy. Reading Research Quarterly, 21(4):360-407.

Street, B. 2003. What's new in new literacy studies? Critical approaches to literacy in theory and practice. Current Issues in Comparative Education, 5(2). Retrieved from 
http://devweb.tc.columbia.edu/i/a/document/25734_5_2_Street.pdf (accessed on 15 July 2013).

Street, B. n.d. Autonomous and ideological models of literacy: Approaches from New Literacy studies. Retrieved from http://www.philbu.net/media-anthropology/ street-newliteracy.pdf (accessed on 13 July 2013).

Teale, W.H. \& Sulzby, E. (Eds). 1986. Emergent literacy: Writing and reading. Norwood, NJ: Ablex.

UN (United Nations). 2012. Millennium Development Goals. Retrieved from http://www. un.org/millenniumgoals (accessed on 28 July 2015).

UNCRC (United Nations Committee on the Rights of the Child). 2005. General Comment 7 on implementing child rights in early childhood. Geneva: OHCHR. Retrieved from http://search.ohchr.org/results.aspx?k=General\%20Comment\%207\#k=General\%20 Comment $\% 207 \% 200$ \%20implementing\%20child\%20rights\%20in\%20early\%20 childhood (accessed on 2 August 2015).

UNESCO (United Nations Educational, Scientific and Cultural Organization). 1990. World Declaration on Education for All. Paris: UNESCO.

Whitehurst, G.J. \& Lonigan, C.J. 1998. Child development and emergent literacy. Child Development, 69:848-872.

Woodhead, M. 2006. Changing perspectives on early childhood education: Theory, research and policy. International Journal of Equity and Innovation in Early Childhood, 4(2):1-43.

Woodhead, M. 2008. Respecting rights: Implications for early childhood policies and practices. In: G. MacNaughton, P. Hughes \& K. Smith (Eds). Young children as active citizens: Principles, policies and pedagogies. Newcastle, U.K: Cambridge Scholars Publishing. 15-30. Retrieved from google.com.au/url?sa=t\&rct=j\&q=\&esrc=s\&source =web\&cd=1\&ved=oCCMQFjAAahUKEwjlzNaR64nHAhUh5aYKHYGBA7U\&url=http\%3 A\%2F\%2Fwww.cambridgescholars.com\%2Fdownload\%2Fsample\%2F61567\&ei=hsG 9 Vc jxGqHKmwWBg46oCw\&usg=AFQjCNGgIG2L7Noe7Gi7vORyPHCUwMc50A\&sig2=c24 sXUztmcVaZKUERA-Dgg\&bvm=bv.99261572,d.dGY (accessed on 2 August 2015).

Woodrow, C., Arthur, L. \& Newman, L. 2014. Futuro Infantil Hoy and Community Capacity Building: An international early childhood literacy project. In: L. Arthur, J. Ashton \& B. Beecher (Eds). Diverse literacies in early childhood: a social justice approach. Melbourne: Australian Council for Educational Research. 86-105.

Woodrow, C., Newman, L., Arthur, L. \& Staples, K. 2011. A funds of knowledge approach to strengthening children's learning. Theme 1. Sydney: University of Western Sydney, Futuro Infantil Hoy research team.

Yoncheva, Y.N., Wise, J. \& McCandliss, B. 2015. Hemispheric specialization for visual words is shaped by attention to sublexical units during initial learning. Brain and Language, 145-146:23-33.

Zippin, L., Sellar, S. \& Hattam, R. 2012. Countering and exceeding capital - A funds of knowledge approach to re-imagining community. Discourse - Studies in the cultural politics of education, 33(2):179-192. 